\title{
PRZYMIOT STRONY W POSTĘPOWANIU W SPRAWIE ZATWIERDZENIA PLANU RUCHU PODZIEMNEGO ZAKŁADU GÓRNICZEGO ORAZ LIKWIDOWANEGO (LIKWIDOWANEJ OZNACZONEJ CZĘŚCI) PODZIEMNEGO ZAKŁADU GÓRNICZEGO (CZĘŚĆ I)
}

THE ATTRIBUTE OF A PARTY TO THE PROCEEDINGS ON THE APPROVAL OF A MOVEMENT PLAN OF UNDERGROUND MINING ENTERPRISE AND OF ENTERPRISE UNDER LIQUIDATION (LIQUIDATION OF A SPECIFIC PART) (PART I)

\section{STRESZCZENIE}

Artykuł jest próbą udzielenia odpowiedzi na pytanie, czy poza przedsiębiorcą, który występuje z żądaniem zatwierdzenia planu ruchu podziemnego zakładu górniczego lub likwidowanego (likwido-

* Magister prawa, Wyższy Urząd Górniczy w Katowicach. 
wanej oznaczonej części) podziemnego zakładu górniczego, w postępowaniach administracyjnych $\mathrm{w}$ sprawach zatwierdzenia tych dokumentów przymiot strony może przysługiwać innym jeszcze osobom. W poprzednim stanie prawnym, na tle art. 64 i 65 ustawy z dnia 4 lutego 1994 r. - Prawo geologiczne i górnicze, w orzecznictwie sądów administracyjnych wyrażany został pogląd, zgodnie z którym prawa strony w postępowaniu dotyczącym zatwierdzenia planu ruchu zakładu górniczego przysługują wyłącznie przedsiębiorcy występującemu o zatwierdzenie planu ruchu i brak jest możliwości przyznania statusu strony wymienionego postępowania innym podmiotom niż wnioskodawca. Artykuł stanowi więc również próbę oceny aktualności tego poglądu w aktualnym stanie prawnym, na tle regulacji art. 108 i 109 ustawy z dnia 9 czerwca 2011 r. - Prawo geologiczne i górnicze, w zakresie odnoszącym się do zatwierdzenia dwóch wspomnianych planów ruchu.

Artykuł składa się z dwóch części. W części pierwszej zawarto uwagi wstępne, wyjaśniono pojęcie planu ruchu, przybliżono definicję strony sformułowaną w art. 28 ustawy z dnia 14 czerwca 1960 r. - Kodeks postępowania administracyjnego oraz przeanalizowano kwestię przymiotu strony postępowania $\mathrm{w}$ sprawie zatwierdzenia planu ruchu podziemnego zakładu górniczego. Analizie poddano postanowienia (elementy) ujmowane $\mathrm{w}$ tym planie, których treść może mieć znaczenie dla sfery interesów prawnych osób innych niż przedsiębiorca, w szczególności dla właścicieli (użytkowników wieczystych) nieruchomości, zlokalizowanych w granicach terenu górniczego.

\section{Słowa kluczowe}

Strona postępowania, plan ruchu, podziemny zakład górniczy.

\section{ABSTRACT}

The aim of the present article is to answer the question of whether, apart from an entrepreneur who makes a request for approval of a movement plan of underground mining enterprise or of underground mining enterprise under liquidation (liquidation of a specific part) in the administrative proceedings, the attribute of a party may be granted to other subject. Under the previous legal regime, on the ground of Articles 64 and 65 of the Act of 4 February 1994 - Geological and Mining Law, the administrative courts in its jurisprudence 
expressed a view according to which the right of a party in the proceedings on the approval of a mining enterprise's movement plan may be attributed solely to an entrepreneur making request for approval of a movement plan and there was no possibility to grant the status of a party in the above proceedings to other subjects. This article thus also attempts to assess the relevance of the above view under the present legal regime against the background of Articles 108 and 109 of the Act of 9 June 2011 - the Geological and Mining Law as far as it concerns the approval of the two mentioned movement plans.

The present article consists of two parts. The first part concentrates on giving introductory remarks. At the beginning the notion of a movement plan is explained, as well as the definition of a party under Article 28 of the Code of Administrative Proceedings of 14 June 1960 is described. Subsequently, the article analyses the question of the attribute of a party to the proceedings on the approval of an underground mining enterprise's movement plan. The article also discusses the provisions (elements) included in this plan, the content of which may be relevant to the legal interests' sphere of persons other than an entrepreneur, in particular to real estate owners (perpetual lessees) whose properties are located within the mining area.

\section{Keywords}

Party to the proceedings, movement plan, underground mining enterprise.

\section{UWAGI WSTĘPNE}

Niniejszy artykuł stanowi próbę udzielenia odpowiedzi na pytanie, czy poza przedsiębiorcą, czyli stosownie do art. 6 ust. 1 pkt 9 ustawy z dnia 9 czerwca 2011 r. - Prawo geologiczne i górnicze ${ }^{1}$, podmiotem posiadającym koncesję na prowadzenie działalności regulowanej tą ustawą, który występuje z wnioskiem o zatwierdzenie planu ruchu podziemnego zakładu górniczego lub likwidowanego (likwidowanej oznaczonej części) podziemnego zakładu górniczego, w postępowaniach admini-

1 Dz.U. z 2011 r. Nr 163, poz. 981 ze zm., dalej „p.g.g.”. 
stracyjnych dotyczących zatwierdzenia tych dokumentów status strony może przysługiwać innym jeszcze osobom² ${ }^{2}$.

Przedsiębiorca wnioskujący o zatwierdzenie planu ruchu zakładu górniczego powinien najpierw uzyskać koncesję na prowadzenie działalności regulowanej p.g.g. ${ }^{3}$ Postępowanie więc $\mathrm{w}$ przedmiocie zatwierdzenia planu ruchu poprzedzone jest postępowaniem $\mathrm{w}$ sprawie udzielenia koncesji ${ }^{4}$. Obydwa wymienione postępowania administracyjne poprzedzają natomiast rozpoczęcie ruchu zakładu górniczego (działalności określonej koncesją). Chociażby z tej przyczyny, w świetle przepisów p.g.g., koncesja i plan ruchu są instrumentami wzajemnie powiązanymi. W szczególności, w myśl art. 108 ust. 3 p.g.g., plan ruchu zakładu górniczego sporządza się z uwzględnieniem warunków określonych m.in. w koncesji. Niejako z drugiej strony, w praktyce organy koncesyjne często, określając w decyzji koncesyjnej, na podstawie art. 30 ust. 1 pkt 4 p.g.g., termin rozpoczęcia działalności objętej koncesją, oprócz podawania konkretnej daty, wskazują również na konieczność uprzedniego sporządzenia planu ruchu i uzyskania ostatecznej decyzji zatwierdzającej ten plan.

Pomimo powyższych zależności pomiędzy koncesją i planem ruchu zakładu górniczego należy jednak zaznaczyć, że postępowanie o udzielenie koncesji oraz postępowanie w przedmiocie zatwierdzenia planu ruchu są odrębnymi postępowaniami administracyjnymi, prowadzonymi przy tym przez różne organy

2 Zgodnie z art. 6 ust. 1 pkt 18 p.g.g. zakładem górniczym jest wyodrębniony technicznie i organizacyjnie zespół środków służących bezpośrednio do wykonywania działalności regulowanej ustawą w zakresie wydobywania kopalin ze złóż, a w podziemnych zakładach górniczych wydobywających węgiel kamienny wraz z pozostającym w związku technologicznym z wydobyciem kopaliny przygotowaniem wydobytej kopaliny do sprzedaży, podziemnego bezzbiornikowego magazynowania substancji, podziemnego składowania odpadów albo podziemnego składowania dwutlenku węgla, w tym wyrobiska górnicze, obiekty budowlane, urządzenia oraz instalacje.

3 Por. w szczególności art. 108 ust. 10 p.g.g., który przewiduje, że wraz z wnioskiem o zatwierdzenie planu ruchu zakładu górniczego przekazuje się do wglądu m.in. odpis koncesji.

4 Zob. art. 21 i nast. p.g.g. 
administracji publicznej5. W konsekwencji w przypadku określonej, planowanej działalności (przedsięwzięcia) kręgi stron postępowań w sprawach udzielenia koncesji oraz zatwierdzenia planu ruchu nie muszą się pokrywać. Innymi słowy, okoliczność, że dana osoba została uznana za stronę w postępowaniu dotyczącym np. udzielenia koncesji na wydobywanie kopaliny ze złoża X metodą odkrywkową, nie oznacza wcale, że osoba ta będzie miała przymiot strony w postępowaniu w sprawie zatwierdzenia planu ruchu zakładu górniczego, który ma prowadzić eksploatację złoża X.

Stwierdzenie powyższe jest istotne, ponieważ w kwestii statusu strony w postępowaniu koncesyjnym przepisy p.g.g. wprowadziły istotną zmianę $\mathrm{w}$ porównaniu do ustawy $\mathrm{z}$ dnia 4 lutego 1994 r. - Prawo geologiczne i górnicze ${ }^{6}$, która obowiązywała do dnia 31 grudnia 2011 r. ${ }^{7}$ Mianowicie ww. ustawa z dnia 4 lutego 1994 r. nie zawierała uregulowania, które w zakresie postępowania dotyczącego koncesji modyfikowałoby ogólną zasadę z art. 28 ustawy z dnia 14 czerwca 1960 r. - Kodeks postępowania administracyjnego ${ }^{8}$, zgodnie $\mathrm{z}$ którym stroną jest każdy, czyjego interesu prawnego lub obowiązku dotyczy postępowanie albo kto żąda czynności organu ze względu na swój interes prawny lub obowiązek. Na tle takiego stanu prawnego w kwestii przymiotu strony w postępowaniu dotyczącym koncesji w orzecznictwie sądów administracyjnych wyrażane były bardzo różne, a często nawet przeciwstawne sobie poglądy. Przykładowo w wyroku z dnia 17 kwietnia 2002 r. NSA stwierdził, że stronami postępowania administracyjnego dotyczącego koncesji (udzielenia koncesji, jej cofnięcia lub ograniczenia, czy też stwierdzenia wygaśnięcia koncesji) są: organ administracji państwowej uprawniony do udzielenia koncesji oraz podmiot

5 Stosownie do art. 22 p.g.g. organami koncesyjnymi są: minister właściwy do spraw środowiska, starosta i marszałek województwa. Natomiast, zgodnie z art. 108 ust. 11 p.g.g., plan ruchu zakładu górniczego zatwierdza właściwy organ nadzoru górniczego, którym w praktyce jest dyrektor właściwego okręgowego urzędu górniczego (art. 164 ust. 1 pkt 2 p.g.g.).

6 Tj. Dz.U. z 2005 r. Nr 228, poz. 1947 ze zm.

7 Por. art. 226 i 227 p.g.g.

8 Tj. Dz.U. z 2013 r. poz. 267, dalej „k.p.a.”. 
gospodarczy, który się o tę koncesję ubiega (bądź którego koncesja ta dotyczy) oraz że ww. organ i podmiot gospodarczy są stronami powstałego w następstwie decyzji koncesyjnej stosunku administracyjno-prawnego ${ }^{9}$. Poza tym $\mathrm{w}$ wielu orzeczeniach sądy odmawiały statusu strony w postępowaniu dotyczącym koncesji właścicielowi nieruchomości, zlokalizowanej w granicach terenu górniczego ${ }^{10}$. Z drugiej strony, w wyroku NSA z dnia 6 czerwca 2006 r. $^{11}$ przedstawione zostało stanowisko, w myśl którego osobom prowadzącym działalność gospodarczą na terenie górniczym jako przestrzeni objętej przewidywanym szkodliwym wpływem robót górniczych, przysługują uprawnienia strony postępowania w sprawach dotyczących legalności koncesji na wydobywanie kopalin - w części określającej granice terenu górniczego ${ }^{12}$.

W aktualnym stanie prawnym, w zakresie statusu strony w postępowaniu dotyczącym koncesji regulacje art. 41 ust. 1 i 2 p.g.g. wprowadziły modyfikację względem ogólnej zasady z art. 28 k.p.a. Stosownie do art. 41 ust. 1 p.g.g., jeżeli ustawa nie stanowi inaczej, stronami postępowań prowadzonych na podstawie działu III cyt. ustawy (zatytułowanego „Koncesje”) w odniesieniu do działalności wykonywanej w granicach nieruchomości gruntowych są ich właściciele (użytkownicy wieczyści). Z kolei art. 41 ust. 2 p.g.g. stanowi, że stronami postępowań prowadzonych na podstawie działu III ww. ustawy nie są właściciele

9 Sygn. akt II SA 966/01, LEX 157881.

10 Por. wyrok NSA z dnia 26 listopada 2008 r., sygn. akt II GSK 504/08, LEX 536796, wyroki WSA w Warszawie: z dnia 17 kwietnia 2009 r., sygn. akt VI SA/Wa 74/09, LEX 651114, z dnia 29 kwietnia 2009 r., sygn. akt VI SA/Wa 339/09, LEX 650496, z dnia 17 czerwca 2009 r., sygn. akt VI SA/Wa 728/09, LEX 651108 i z dnia 21 grudnia 2009 r., sygn. akt VI SA/Wa 1732/09, LEX 583565, oraz wyrok WSA w Olsztynie z dnia 6 grudnia 2011 r., sygn. akt II SA/Ol 734/11, LEX 1096978.

11 Sygn. akt II GSK 59/06, OSP 2007, nr 4, poz. 42, z glosą H. Knysiak-Molczyk; LEX 238813.

12 Szerzej na temat przymiotu strony w postępowaniu dotyczącym koncesji na tle uchylonej ustawy z dnia 4 lutego 1994 r. - Prawo geologiczne i górnicze zob. R. Mikosz, Strona $w$ postępowaniu dotyczacym koncesji na wydobywanie kopalin [w:] Ratio est anima legis. Księga jubileuszowa ku czci Profesora Janusza Trzcińskiego, Warszawa 2007, s. 275-290. 
(użytkownicy wieczyści) nieruchomości znajdujących się poza granicami projektowanego albo istniejącego obszaru górniczego lub miejscami wykonywania robót geologicznych ${ }^{13}$.

Jeśli chodzi o przymiot strony $\mathrm{w}$ postępowaniu administracyjnym w sprawie zatwierdzenia planu ruchu zakładu górniczego w uchylonej ustawie z dnia 4 lutego 1994 r. - Prawo geologiczne i górnicze brak było uregulowania, które modyfikowałoby w zakresie wspomnianego postępowania ogólną zasadę z art. 28 k.p.a. W takim stanie prawnym, na tle art. 64 i 65 cyt. ustawy, w wyroku Naczelnego Sądu Administracyjnego oz. w Katowicach z dnia 29 sierpnia 2000 r. $^{14}$ oraz w trzech wyrokach Wojewódzkiego Sądu Administracyjnego w Gliwicach z dnia 10 maja 2004 r. ${ }^{15}$ wyrażone zostało stanowisko, zgodnie $\mathrm{z}$ którym prawa strony $\mathrm{w}$ postępowaniu administracyjnym dotyczącym zatwierdzenia planu ruchu zakładu górniczego przysługują jedynie przedsiębiorcy występującemu o zatwierdzenie planu ruchu i brak jest możliwości przyznania przymiotu strony wymienionego postępowania innym podmiotom niż wnioskodawca. Stany faktyczne spraw, które zostały rozstrzygnięte ww. orzeczeniami, dotyczyły projektowania ruchu podziemnych zakładów górniczych. Z kolei pogląd, w myśl którego stroną postępowania administracyjnego w sprawie zatwierdzenia planu ruchu zakładu górniczego jest wyłącznie przedsiębiorca występujący z żądaniem zatwierdzenia planu ruchu, miał charakter uniwersalny, w tym sensie, że można go było odnieść do postępowania dotyczącego zatwierdzenia planu ruchu każdego zakładu górniczego. Poza sytuacją zatem zatwierdzenia planu ruchu podziemnego zakładu górniczego, przedstawione stanowisko dotyczyło również zatwierdzenia planu ruchu odkrywkowego zakładu górniczego oraz zakładu górniczego wydobywającego

13 W tym zakresie zob. wyrok NSA z dnia 25 marca 2013 r., sygn. akt II GSK 2322/11, LEX 1334127, w którego uzasadnieniu Sąd stwierdził m.in., że według nowych przepisów stroną postępowania koncesyjnego nie może być właściciel (użytkownik wieczysty) nieruchomości znajdującej się w granicach projektowanego terenu górniczego.

14 Sygn. akt II SA/Ka 1650/99, niepubl.

15 Sygn. akt: II SA/Ka 490/02, LEX 699753, II SA/Ka 752/03, LEX 720761 i II SA/Ka 1701/03, LEX 719757. 
kopaliny otworami wiertniczymi. Innymi słowy, pogląd NSA oz. w Katowicach oraz WSA w Gliwicach odnosił się zarówno do górnictwa podziemnego, odkrywkowego, jak i otworowego.

Aktualnie obowiązujące p.g.g., podobnie jak uchylona ustawa z dnia 4 lutego 1994 r. - Prawo geologiczne i górnicze, nie zawiera regulacji, która w zakresie statusu strony postępowania $\mathrm{w}$ sprawie zatwierdzenia planu ruchu wprowadzałaby modyfikację względem ogólnej zasady z art. 28 k.p.a. W konsekwencji pojawia się pytanie, czy stanowisko, zgodnie z którym stroną postępowania $\mathrm{w}$ przedmiocie zatwierdzenia planu ruchu zakładu górniczego jest tylko przedsiębiorca wnioskujący o zatwierdzenie tego dokumentu, zachowało aktualność w obecnym stanie prawnym, na tle art. 108 i 109 p.g.g. Niniejszy artykuł stanowi więc także próbę weryfikacji na tle nowego stanu prawnego poglądu zaprezentowanego przez NSA oz. w Katowicach i WSA w Gliwicach. Ze względu na ograniczone ramy opracowania analiza została zawężona do postępowań w sprawach zatwierdzenia plan ruchu podziemnego zakładu górniczego oraz likwidowanego (likwidowanej oznaczonej części) podziemnego zakładu górniczego. W toku dalszych rozważań należy więc mieć także na uwadze, że w podziemnych zakładach górniczych roboty górnicze ${ }^{16}$, prowadzone są głównie w przestrzeni objętej własnością górniczą, która z mocy art. 10 ust. 5 p.g.g. przysługuje Skarbowi Państwa, czyli poza granicami przestrzennymi nieruchomości gruntowej.

Przepisy p.g.g., tak jak poprzednio obowiązującej ustawy z dnia 4 lutego 1994 r. - Prawo geologiczne i górnicze, nie udzielają odpowiedzi na pytanie, czy poza przedsiębiorcą wnioskującym o zatwierdzenie planu ruchu podziemnego zakładu górniczego lub likwidowanego (likwidowanej oznaczonej części) podziemnego zakładu górniczego w postępowaniu dotyczącym zatwierdzenia tych dokumentów status strony może przysługiwać także innym podmiotom. W literaturze kwestia przymiotu

16 Zgodnie z art. 6 ust. 1 pkt 12 p.g.g., robotą górniczą jest wykonywanie, utrzymywanie, zabezpieczanie lub likwidowanie wyrobisk górniczych oraz zwałowanie nadkładu w odkrywkowych zakładach górniczych w związku z działalnością regulowaną ustawą. 
strony postępowania w sprawie zatwierdzenia ww. planów ruchu nie doczekała się do tej pory szerszego opracowania.

W orzecznictwie na tle art. 64 i art. 65 uchylonej ustawy z dnia 4 lutego 1994 r. - Prawo geologiczne i górnicze przedstawiono stanowisko, w myśl którego przywołane regulacje prawne nie tworzyły po stronie gminy, na obszarze której prowadzone było wydobycie kopaliny w podziemnym zakładzie górniczym, legitymacji do bycia stroną $\mathrm{w}$ postępowaniu dotyczącym zatwierdzenia planu ruchu lub zmian do tego planu ${ }^{17}$. Nadto w sprawie obejmującej zatwierdzenie części szczegółowej planu ruchu podziemnego zakładu górniczego odmówiono statusu strony organowi wykonawczemu gminy ${ }^{18}$. Poza tym w sprawie dotyczącej zatwierdzenia części szczegółowej planu ruchu podziemnego zakładu górniczego wyrażono pogląd, zgodnie $\mathrm{z}$ którym przymiotu strony $\mathrm{w}$ postępowaniu administracyjnym w przedmiocie zatwierdzenia planu ruchu nie ma sołectwo ${ }^{19}$.

Wspomniane wcześniej wyroki, w których przedstawiono stanowisko, że status strony w postępowaniu w sprawie zatwierdzenia planu ruchu zakładu górniczego przysługuje jedynie przedsiębiorcy występującemu o zatwierdzenie planu ruchu, obejmowały natomiast stany faktyczne dotyczące zatwierdzenia części szczegółowej planu ruchu podziemnego zakładu górni-

17 Tak WSA w Gliwicach w wyrokach: z dnia 20 lipca 2005 r., sygn. akt III SA/Gl 596/04, LEX 828784 i z dnia 14 września 2005 r., sygn. akt III SA/Gl 353/04, niepubl.

18 Por. wyrok WSA w Gliwicach z dnia 31 października 2006 r., sygn. akt III SA/Gl 457/05, LEX 878616. Zob. również postanowienie NSA oz. w Katowicach z dnia 14 grudnia 1998 r., sygn. akt II SA/Ka 2313/98, niepubl., w którym odmówiono przymiotu strony organowi wykonawczemu gminy w sprawie dotyczącej zatwierdzenia dodatku do planu ruchu na wykonywanie prac sejsmicznych, oraz wyrok WSA w Gliwicach z dnia 20 lutego 2008 r., sygn. akt III SA/Gl 1384/07, LEX 490814, w którym w sprawie obejmującej zatwierdzenie planu ruchu zakładu górniczego wykonującego roboty geologiczne, polegające na odwierceniu otworu badawczego dla rozpoznania złoża węgla kamiennego, za stronę nie został uznany wójt gminy.

19 Wyrok NSA oz. w Katowicach z dnia 29 sierpnia 2000 r. (zob. przypis nr 14). 
czego $^{20}$ oraz dodatków do części podstawowej i szczegółowej planu ruchu podziemnego zakładu górniczego ${ }^{21}$. We wszystkich czterech wymienionych orzeczeniach przywołano przy tym wyrok NSA oz. w Katowicach z dnia 23 czerwca 1999 r., w którym najprawdopodobniej wyrażono taki sam pogląd ${ }^{22}$.

Odmienne stanowisko zajął z kolei NSA oz. w Katowicach w wyroku z dnia 9 listopada $2001 \mathrm{r}^{23}$, stwierdzając, że w sytuacji, gdyby gmina wykazała, iż postępowanie administracyjne w przedmiocie zatwierdzenia części szczegółowej planu ruchu likwidowanego podziemnego zakładu górniczego dotyczy jej interesu prawnego lub obowiązku, to miałaby w tym postępowaniu przymiot strony. W orzeczeniu tym Sąd w zakresie projektowania ruchu likwidowanego podziemnego zakładu górniczego dopuścił więc sytuację, w której poza przedsiębiorcą występującym z wnioskiem o zatwierdzenie planu ruchu status strony $\mathrm{w}$ postępowaniu $\mathrm{w}$ sprawie zatwierdzenia planu ruchu zakładu górniczego może przysługiwać innym jeszcze osobom.

Z treści przedstawionych orzeczeń wynika więc, że w czasie obowiązywania ustawy z dnia 4 lutego 1994 r. - Prawo geologiczne i górnicze w judykaturze nie było jednolitego poglądu w kwestii przymiotu strony postępowania administracyjnego w przedmiocie zatwierdzenia planu ruchu podziemnego zakładu górniczego lub likwidowanego (likwidowanej oznaczonej części) podziemnego zakładu górniczego.

W ocenie autora w praktyce istnieje problem $\mathrm{z}$ kwalifikacją osób, na których prawnie chronione interesy ma oddziaływać projektowany ruch podziemnego zakładu górniczego jako stron postępowania administracyjnego $\mathrm{w}$ sprawie zatwierdzenia planu ruchu. Poruszone zagadnienie ma przy tym duże znaczenie dla organów nadzoru górniczego. Przede wszystkim należy za-

20 Wyroki: NSA oz. w Katowicach z dnia 29 sierpnia 2000 r. (zob. przypis nr 14) oraz WSA w Gliwicach z dnia 10 maja 2004 r., sygn. akt II SA/Ka 490/02 (zob. przypis nr 15).

21 Wyroki WSA w Gliwicach z dnia 10 maja 2004 r., sygn. akt: II SA/Ka 752/03 i II SA/Ka 1701/03 (zob. przypis nr 15).

22 Sygn. akt II SA/Ka 1546/97, niepubl. Niestety autorowi nie udało się dotrzeć do treści tego orzeczenia.

23 Sygn. akt II SA/Ka 2331/99, niepubl. 
uważyć, że to na organie nadzoru górniczego ciąży obowiązek zidentyfikowania wszystkich stron postępowania w przedmiocie zatwierdzenia planu ruchu podziemnego zakładu górniczego lub likwidowanego (likwidowanej oznaczonej części) podziemnego zakładu górniczego i stosownie do art. $10 \S 1$ k.p.a. zapewnienia im czynnego udziału w sprawie. Zgodnie $\mathrm{z}$ art. $145 \S 1$ pkt 4 k.p.a. okoliczność, iż strona bez własnej winy nie brała udziału w postępowaniu, stanowi podstawę do wznowienia postępowania administracyjnego. Poza tym, w myśl art. 107 $\S 1$ k.p.a., oznaczenie strony lub stron jest jednym z obligatoryjnych elementów decyzji administracyjnej.

Powyższe względy skłoniły autora do podjęcia próby przeanalizowania problematyki statusu strony w postępowaniu dotyczącym zatwierdzenia planu ruchu podziemnego zakładu górniczego oraz likwidowanego (likwidowanej oznaczonej części) podziemnego zakładu górniczego.

\section{POJĘCIE PLANU RUCHU}

Przed przystąpieniem do próby udzielenia odpowiedzi na pytanie, czy poza przedsiębiorcą występującym o zatwierdzenie planu ruchu podziemnego zakładu górniczego lub likwidowanego (likwidowanej oznaczonej części) podziemnego zakładu górniczego w postępowaniu w sprawie zatwierdzenia ww. planów ruchu status strony może przysługiwać innym osobom, należy jeszcze przybliżyć treść regulacji prawnych odnoszących się do planu ruchu zakładu górniczego oraz wyjaśnić, czym jest ten dokument.

Przepisy dotyczące planu ruchu znajdują się przede wszystkim w rozdziale 2 (zatytułowanym „Ruch zakładu górniczego”) oraz w rozdziale 5 (zatytułowanym „Likwidacja zakładu górniczego"), działu VI p.g.g. Podstawowe znaczenie należy przypisać regulacji art. 105 ust. 1 p.g.g., który stanowi, iż ruch zakładu górniczego prowadzi się w sposób zgodny z przepisami prawa, w szczególności na podstawie planu ruchu zakładu górniczego, a także zgodnie z zasadami techniki górniczej. Z przy- 
toczonego unormowania wynika, że plan ruchu jest jedynym z wyznaczników dozwolonego zachowania się przedsiębiorcy. Stosownie do art. 108 ust. 1 ww. ustawy plan ruchu zakładu górniczego sporządza przedsiębiorca, odrębnie dla każdego zakładu górniczego. Zgodnie z art. 108 ust. 3 p.g.g. plan ruchu zakładu górniczego sporządza się z uwzględnieniem warunków określonych $\mathrm{w}$ koncesji oraz odpowiednio $\mathrm{w}$ projekcie zagospodarowania złoża albo w planie zagospodarowania podziemnego składowiska dwutlenku węgla, a w przypadku: (1) robót geologicznych, których wykonywanie nie wymaga koncesji - z uwzględnieniem warunków określonych w projekcie robót geologicznych, (2) działalności określonej w art. 2 ust. 1 cyt. ustawy - z uwzględnieniem warunków lokalnych jej prowadzenia. W myśl art. 108 ust. 6 p.g.g. plan ruchu sporządza się na okres od 2 do 6 lat albo na cały planowany okres prowadzenia ruchu, jeżeli jest on krótszy ${ }^{24}$. Plan ruchu zakładu górniczego podlega zatwierdzeniu, w drodze decyzji, przez właściwy organ nadzoru górniczego, po uzyskaniu opinii organu wykonawczego gminy (art. 108 ust. 11 ww. ustawy).

Nadto w przypadku likwidacji całości lub części zakładu górniczego sporządza się odrębny plan ruchu. Dokument ten określany jest jako plan ruchu likwidowanego (likwidowanej oznaczonej części) zakładu górniczego i podobnie jak „zwykły” plan ruchu podlega zatwierdzeniu, w drodze decyzji, przez właściwy organ nadzoru górniczego. Stosownie do art. 129 ust. 5 zd. 1 p.g.g. zatwierdzenie planu ruchu likwidowanego (likwidowanej oznaczonej części) zakładu górniczego wymaga już jednak uzgodnienia z właściwym wójtem (burmistrzem, prezydentem miasta).

W zakresie zawartości planu ruchu zakładu górniczego należy w pierwszej kolejności zwrócić uwagę na art. 108 ust. 2 cyt. ustawy, zgodnie z którym plan ruchu określa: (1) strukturę organizacyjną zakładu górniczego, w szczególności przez

24 Wyjątek w tym zakresie przewiduje art. 108 ust. 6a p.g.g., zgodnie z którym plan ruchu zakładu górniczego prowadzącego podziemne składowanie dwutlenku węgla sporządza się na okres pięciu lat albo na cały planowany okres prowadzenia ruchu, jeżeli jest on krótszy. 
wskazanie stanowisk osób kierownictwa i dozoru ruchu oraz (2) szczegółowe przedsięwzięcia niezbędne w celu zapewnienia: (a) wykonywania działalności objętej koncesją, (b) bezpieczeństwa powszechnego, (c) bezpieczeństwa pożarowego, (d) bezpieczeństwa osób przebywających w zakładzie górniczym, w szczególności dotyczące bezpieczeństwa i higieny pracy, (e) racjonalnej gospodarki złożem, (f) ochrony elementów środowiska, (g) ochrony obiektów budowlanych oraz (h) zapobiegania szkodom i ich naprawy ${ }^{25}$. Z kolei, w myśl art. 129 ust. 4 p.g.g. w zw. z ust. 1 tego artykułu, plan ruchu likwidowanego zakładu górniczego lub jego oznaczonej części określa również sposób wykonania obowiązków dotyczących zabezpieczenia lub likwidacji wyrobisk górniczych oraz urządzeń, instalacji i obiektów zakładu górniczego, zabezpieczenia niewykorzystanej części złoża kopaliny, zabezpieczenia sąsiednich złóż kopalin, przedsięwzięcia niezbędnych środków chroniących wyrobiska sąsiednich zakładów górniczych, podjęcia niezbędnych środków w celu ochrony środowiska oraz rekultywacji gruntów po działalności górniczej.

Szczegółowe wymagania odnośnie do treści planu ruchu zakładu górniczego oraz planu ruchu likwidowanego (likwidowanej oznaczonej części) zakładu górniczego określa rozporządzenie Ministra Środowiska z dnia 16 lutego 2012 r. w sprawie planów ruchu zakładów górniczych ${ }^{26}$, wydane na podstawie delegacji zawartej $\mathrm{w}$ art. 110 p.g.g. W istocie to właśnie przy-

25 Zgodnie z art. 108 ust. 2a p.g.g., plan ruchu zakładu górniczego prowadzącego podziemne składowanie dwutlenku węgla określa również przedsięwzięcia niezbędne $\mathrm{w}$ celu zapewnienia bezpieczeństwa podziemnego składowania dwutlenku węgla, w tym: (1) przedsięwzięcia mające na celu zapobieżenie wystąpieniu wycieków dwutlenku węgla oraz wydostaniu się dwutlenku węgla poza kompleks podziemnego składowania dwutlenku węgla, a także przedsięwzięcia mające na celu zapobieżenie innym nieprawidłowościom w procesie podziemnego składowania dwutlenku węgla, które mogą powodować zagrożenie bezpieczeństwa powszechnego lub zdrowia i życia ludzi oraz środowiska, (2) działania naprawcze oraz (3) przedsięwzięcia, które będą podejmowane po zamknięciu podziemnego składowiska dwutlenku węgla, ze szczególnym uwzględnieniem ich uwarunkowań technicznych. chu".

26 Dz.U. z 2012 r. poz. 372, dalej „rozporządzenie w sprawie planów ru- 
wołane rozporządzenie rozstrzyga o tym, co powinno znaleźć się w planie ruchu danego zakładu górniczego. W załącznikach do rozporządzenia w sprawie planów ruchu zostały ujęte szczegółowe wymagania dotyczące treści planów ruchu w stosunku do poszczególnych rodzajów zakładów górniczych oraz likwidowanych (likwidowanych oznaczonych części) zakładów górniczych. Wzór planu ruchu dla podziemnego zakładu górniczego określa załącznik nr 1 do rozporządzenia w sprawie planów ruchu, a dla likwidowanego (likwidowanej oznaczonej części) podziemnego zakładu górniczego załącznik nr 8 do tego rozporządzenia.

W zakresie pojęcia planu ruchu zakładu górniczego w literaturze zaprezentowano stanowisko, zgodnie z którym plan ruchu jest chronologicznie ostatnim instrumentem $\mathrm{w}$ ciągu zdarzeń prawnych konkretyzujących zakres, treść oraz sposób wykonania praw i obowiązków podmiotu prowadzącego ruch zakładu górniczego. Decyzja zatwierdzająca ten plan jest więc wyznacznikiem granic dozwolonego zachowania się uprawnionego podmiotu. Plan ruchu musi uwzględniać warunki określone w koncesji oraz w projekcie zagospodarowania złoża. Nie może zatem przewidywać działań, które nie mieściłyby się w granicach wyznaczonych za pomocą ww. instrumentów. Funkcja planu ruchu zakładu górniczego powinna polegać przede wszystkim na konkretyzacji tych granic, w szczególności przez wskazanie rodzajów dozwolonych zachowań (przedsięwzięć), sposobu ich realizacji, obowiązków z tym związanych itp. ${ }^{27}$ Zdaniem autora pogląd ten, choć wyrażony na tle art. 64 uchylonej ustawy z dnia 4 lutego 1994 r. - Prawo geologiczne i górnicze, zachował swą aktualność po wejściu w życie nowej ustawy i można w pełni odnieść go do treści art. 108 p.g.g. Do powyższego stanowiska można jedynie dodać, że w przypadku podziemnego zakładu górniczego plan ruchu jest dokumentem bardzo obszernym oraz że jest to instrument o podstawowym znaczeniu dla funkcjonowania zakładu górniczego. 


\section{KODEKSOWE POJĘCIE STRONY POSTĘPOWANIA ADMINISTRACYJNEGO}

Przed podjęciem analizy kwestii przymiotu strony w postępowaniu $\mathrm{w}$ przedmiocie zatwierdzenia planu ruchu podziemnego zakładu górniczego lub likwidowanego (likwidowanej oznaczonej części) podziemnego zakładu górniczego, należy też przybliżyć niektóre poglądy judykatury i doktryny wyrażone na tle regulacji art. 28 k.p.a., gdyż mogą one okazać się pomocne w rozstrzygnięciu wątpliwości dotyczących strony postępowania w sprawie zatwierdzenia wspomnianych planów ruchu. Przypomnijmy, że stosownie do art. 28 k.p.a., stroną jest każdy, czyjego interesu prawnego lub obowiązku dotyczy postępowanie albo kto żąda czynności organu ze względu na swój interes prawny lub obowiązek. W literaturze zacytowany przepis nie jest interpretowany jednolicie. W szczególności część autorów opowiada się za tzw. subiektywną (procesową, formalną) teorią strony, zgodnie z którą stroną jest każdy, kto twierdzi wobec organu administracyjnego, że postępowanie dotyczy jego interesu prawnego (obowiązku lub uprawnienia), albo kto żąda czynności organu, powołując się na istniejący, zdaniem jego, interes prawny lub obowiązek (strona jest pojęciem procesowym, a nie kategorią prawa materialnego). Zwolennicy koncepcji subiektywnej interes prawny utożsamiają z „prawem do postępowania” w znaczeniu czysto proceduralnym. Wyróżnia się również tzw. obiektywną (materialną) teorię strony, której przedstawiciele podstawę legitymacji strony upatrują $\mathrm{w}$ interesie opartym na prawie, a więc w stosunku materialnoprawnym określonym w przepisie prawnym umieszczonym poza k.p.a. Reprezentanci tej koncepcji przez interes prawny rozumieją interes mający źródło $\mathrm{w}$ prawie materialnym ${ }^{28}$.

W orzecznictwie sądów administracyjnych na ogół wskazuje się, że tylko przepis prawa materialnego, stanowiąc pod-

28 Por. A. Wróbel [w:] M. Jaśkowska, A. Wróbel, Kodeks postępowania administracyjnego. Komentarz, wyd. 3, Warszawa 2009, s. 213 i nast. 
stawę interesu prawnego, stwarza dla określonego podmiotu legitymację procesową strony ${ }^{29}$, a mieć interes prawny w postępowaniu administracyjnym, znaczy to samo, co ustalić przepis prawa materialnego, na którego podstawie można skutecznie żądać czynności organu z zamiarem zaspokojenia jakiejś własnej potrzeby albo żądać zaniechania lub ograniczenia czynności organu, sprzecznych z potrzebami danego podmiotu - strony postępowania ${ }^{30}$. W judykaturze dominuje więc tzw. obiektywna (materialna) teoria strony ${ }^{31}$.

Ponadto w orzecznictwie przyjmuje się, że źródłem interesu prawnego w rozumieniu art. 28 k.p.a. mogą być nie tylko normy materialnego prawa administracyjnego, ale także prawa finansowego, ubezpieczeń społecznych, prawa cywilnego czy prawa pracy $^{32}$. Zwraca się przy tym uwagę, że interes prawny w postępowaniu administracyjnym może wynikać w szczególności z prawa rzeczowego, zwłaszcza z prawa własności lub prawa użytkowania wieczystego nieruchomości ${ }^{33}$.

Z punktu widzenia analizowanego zagadnienia szczególnie interesująca jest koncepcja interesu prawnego wynikającego z tzw. prawa refleksowego. W myśl tej koncepcji, postępowanie administracyjne dotyczy interesu prawnego określonej

29 Tak NSA w wyrokach: z dnia 12 stycznia 2012 r., sygn. akt II OSK 2035/10, LEX 1121192 i z dnia 12 lipca 2012 r., sygn. akt I OSK 1005/11, LEX 1260011.

30 Tak WSA w Warszawie w wyroku z dnia 8 listopada 2011 r., sygn. akt I SA/Wa 1362/11, LEX 1150708 oraz NSA w wyroku z dnia 9 grudnia 2011 r., sygn. akt II OSK 1791/10, LEX 1152048.

31 Odnośnie materialnej koncepcji strony zob. również wyroki NSA z dnia 17 kwietnia 2012 r., sygn. akt II OSK 176/11, LEX 1219073 i z dnia 19 kwietnia 2012 r., sygn. akt I OSK 531/11, LEX 1218879, wyrok WSA w Krakowie z dnia 25 października 2012 r., sygn. akt III SA/Kr 1533/11, LEX 1235561 oraz wyroki WSA w Warszawie: z dnia 26 października 2011 r., sygn. akt VII SA/Wa 1337/11, LEX 1155837, z dnia 22 listopada 2011 r., sygn. akt I SA/ Wa 2156/10, LEX 1150778, z dnia 16 grudnia 2011 r., sygn. akt VII SA/Wa 1947/11, LEX 1155944 i z dnia 25 stycznia 2012 r., sygn. akt I SA/Wa 974/11, LEX 1113484.

32 Tak NSA w wyroku z dnia 12 lipca 2012 r. (zob. przypis nr 29).

33 Por. wyroki: WSA w Gdańsku z dnia 17 października 2012 r., sygn. akt II SA/Gd 73/12, LEX 1248829 i WSA w Poznaniu z dnia 29 listopada 2012 r., sygn. akt IV SA/Po 1297/11, LEX 1242160. 
osoby wówczas, gdy w postępowaniu wydaje się decyzję, która rozstrzyga o prawach i obowiązkach ww. osoby lub rozstrzygnięcie o prawach i obowiązkach innego podmiotu wpływa na prawa i obowiązki tej osoby. W drugiej z przedstawionych sytuacji określona osoba wywodzi interes prawny do bycia stroną postępowania administracyjnego z tzw. prawa refleksowego. Innymi słowy, status strony postępowania ma nie tylko podmiot, którego dotyczy bezpośrednio postępowanie administracyjne, ale także osoba, której prawnie chronione interesy mogą zostać naruszone poprzez ograniczenie lub uniemożliwienie korzystania z przysługujących jej praw w razie wydania decyzji o określonej treści, skierowanej bezpośrednio do innej osoby ${ }^{34}$. Należy też zauważyć, że w przypadku „strony refleksowej" interes prawny tego podmiotu przemawiający za jego udziałem w postępowaniu będzie wynikał z innych norm prawa materialnego niż te, które stanowią podstawę rozstrzygnięcia o prawach i obowiązkach bezpośredniego adresata decyzji administracyjnej. Natomiast interes prawny bycia stroną $\mathrm{w}$ postępowaniu administracyjnym w rozumieniu art. 28 k.p.a. z tzw. prawa refleksowego może być wywodzony w szczególności z praw właścicielskich ${ }^{35}$.

Autor niniejszego artykułu opowiada się za tzw. obiektywną (materialną) teorią strony. Nadto, w przekonaniu autora, zasadne jest stanowisko, zgodnie z którym źródłem interesu prawnego w rozumieniu art. 28 k.p.a. mogą być normy materialnego prawa cywilnego, $\mathrm{w}$ tym prawa rzeczowego, a interes prawny $\mathrm{w}$ byciu stroną postępowania może $\mathrm{w}$ szczególności wynikać z prawa własności lub użytkowania wieczystego nie-

34 W zakresie strony wywodzącej interes prawny z tzw. prawa refleksowego por. wyrok WSA w Łodzi z dnia 14 października 2011 r., sygn. akt II SA/Łd 650/11, LEX 1153773, wyrok WSA w Warszawie z dnia 28 grudnia 2012 r., sygn. akt VI SA/Wa 1868/12, LEX 1291958 oraz wyroki NSA: z dnia 27 września 2011 r., sygn. akt II GSK 948/10, LEX 1068905 i z dnia 12 stycznia 2012 r. (zob. przypis nr 29) Zob. także A. Matan, [w:] G. Łaszczyca, C. Martysz, A. Matan, Kodeks postępowania administracyjnego. Komentarz do art. 1-103, tom I, wyd. 1, Kraków 2005, s. 315-316 i 322-323.

35 Por. wyrok WSA w Łodzi z dnia 29 lutego 2012 r., sygn. akt III SA/Łd 1201/11, LEX 1146079. 
ruchomości. W ocenie autora za trafną należy również uznać koncepcję strony, której interes prawny w postępowaniu administracyjnym wywodzony jest z tzw. prawa refleksowego.

Nie ulega wątpliwości, że postępowanie w sprawie zatwierdzenia planu ruchu podziemnego zakładu górniczego lub likwidowanego (likwidowanej oznaczonej części) podziemnego zakładu górniczego) dotyczy bezpośrednio sytuacji prawnej przedsiębiorcy występującego z żądaniem zatwierdzenia ww. planów ruchu, a decyzja kończąca postępowanie w sprawie rozstrzyga o prawach i obowiązkach tego podmiotu. Tak więc bez wątpienia stroną postępowania administracyjnego $\mathrm{w}$ przedmiocie zatwierdzenia planu ruchu podziemnego zakładu górniczego lub likwidowanego (likwidowanej oznaczonej części) podziemnego zakładu górniczego jest przedsiębiorca występujący z wnioskiem o zatwierdzenie wymienionych dokumentów i to ta osoba jest bezpośrednim adresatem decyzji organu nadzoru górniczego zatwierdzającej plan ruchu. Rozważenia wymaga natomiast kwestia, czy w postępowaniu dotyczącym zatwierdzenia planu ruchu podziemnego zakładu górniczego lub likwidowanego (likwidowanej oznaczonej części) podziemnego zakładu górniczego przymiot strony może przysługiwać osobom trzecim (podmiotom innym niż przedsiębiorca występujący o zatwierdzenie planu ruchu), których interes prawny $\mathrm{w}$ byciu stroną tego postępowania wynikałby z tzw. prawa refleksowego. W szczególności warto zastanowić się, czy stronami ww. postępowania administracyjnego mogą być właściciele lub użytkownicy wieczyści nieruchomości, zlokalizowanych w granicach terenu górniczego ${ }^{36}$. Zdaniem autora rozstrzygnięcie powyższych kwestii wymaga sięgnięcia do

${ }^{36}$ W myśl art. 6 ust. 1 pkt 15 p.g.g. terenem górniczym jest przestrzeń objęta przewidywanymi szkodliwymi wpływami robót górniczych zakładu górniczego. Stosownie zaś do art. 6 ust. 1 pkt 5 cyt. ustawy, obszarem górniczym jest przestrzeń, w granicach której przedsiębiorca jest uprawniony do wydobywania kopaliny, podziemnego bezzbiornikowego magazynowania substancji, podziemnego składowania odpadów, podziemnego składowania dwutlenku węgla oraz prowadzenia robót górniczych niezbędnych do wykonywania koncesji. Zgodnie z art. 32 ust. 1 p.g.g. granice obszaru i terenu górniczego wyznacza się w koncesji. 
przepisów określających szczegółowe wymagania w zakresie treści planów ruchu dla podziemnego zakładu górniczego oraz likwidowanego w całości lub w części podziemnego zakładu górniczego, czyli do wspomnianego już wcześniej rozporządzenia w sprawie planów ruchu. Szczególnie zasadna wydaje się analiza mająca na celu wskazanie postanowień (elementów) ww. planów ruchu, których realizacja mogłaby na tyle znacząco oddziaływać na sferę interesów prawnych osób trzecich (podmiotów innych niż przedsiębiorca występujący z żądaniem zatwierdzenia wspomnianych planów ruchu), że uzasadniałoby to uznanie tych osób za strony postępowania w sprawie zatwierdzenia planu ruchu zakładu górniczego. Innymi słowy, chodzi o odnalezienie postanowień (elementów) planu ruchu podziemnego zakładu górniczego lub likwidowanego (likwidowanej oznaczonej części) podziemnego zakładu górniczego, których treść może mieć znaczenie dla sfery uprawnień osób trzecich, a ich późniejsze wykonywanie może doprowadzić do naruszenia prawnie chronionych interesów tych osób poprzez ograniczenie lub uniemożliwienie korzystania z przysługujących im praw.

\section{PRZYMIOT STRONY W POSTĘPOWANIU W SPRAWIE ZATWIERDZENIA PLANU RUCHU PODZIEMNEGO ZAKEADU GÓRNICZEGO}

Zgodnie z tym, co zostało już wspomniane, szczegółowe wymagania dotyczące treści planu ruchu podziemnego zakładu górniczego określa załącznik nr 1 do rozporządzenia w sprawie planów ruchu. Poszukując związku pomiędzy treścią planu ruchu podziemnego zakładu górniczego a sferą interesów prawnych podmiotów innych niż przedsiębiorca występujący o zatwierdzenie tego dokumentu, w pierwszej kolejności należy zwrócić uwagę na pkt 23 ww. załącznika. Zgodnie z tym punktem w planie ruchu podziemnego zakładu górniczego ujmowana jest prognoza wpływu działalności górniczej na środowisko 
w okresie obowiązywania koncesji ${ }^{37}$. Stosownie zaś do definicji środowiska zawartej w art. 3 pkt 39 ustawy z dnia 27 kwietnia 2001 r. - Prawo ochrony środowiska ${ }^{38}$, jednym z elementów środowiska jest powierzchnia ziemi ${ }^{39}$. Z powyższego można więc wnioskować, że treść prognozy wpływu działalności górniczej na środowisko ma znaczenie m.in. dla właścicieli (użytkowników wieczystych) nieruchomości, zlokalizowanych w granicach terenu górniczego.

Dla interesów prawnych osób trzecich znaczenie może mieć także element planu ruchu podziemnego zakładu górniczego przewidziany w pkt 24 załącznika nr 1 do rozporządzenia w sprawie planów ruchu, zatytułowany „Ochrona środowiska oraz obiektów budowlanych. Zamierzenia w zakresie zapobiegania i ograniczania szkód wyrządzonych ruchem zakładu górniczego w okresie obowiązywania planu ruchu”. W tym postanowieniu planu ruchu podziemnego zakładu górniczego uwzględnia się m.in.: (ppkt 1) rygory związane z eksploatacją złoża w granicach filarów ochronnych wyznaczonych dla dóbr wymagających ochrony ${ }^{40}$, w tym: (a) środki profilaktyki górni-

37 Art. 21 ust. 4 p.g.g. stanowi, że koncesji udziela się na czas oznaczony, nie krótszy niż 3 lata i nie dłuższy niż 50 lat, chyba że przedsiębiorca złożył wniosek o udzielenie koncesji na czas krótszy. Wyjątek przewiduje art. 21 ust. 4a cyt. ustawy, w myśl którego koncesji na podziemne składowanie dwutlenku węgla udziela się na okres uwzględniający obowiązek prowadzenia po zamknięciu podziemnego składowiska dwutlenku węgla monitoringu kompleksu podziemnego składowania dwutlenku węgla przez okres nie krótszy niż dwadzieścia lat.

38 Tj. Dz.U. z 2013 r. poz. 1232 ze zm.

39 W myśl art. 3 pkt 39 ustawy z dnia 27 kwietnia 2001 r. - Prawo ochrony środowiska, przez środowisko należy rozumieć ogół elementów przyrodniczych, w tym także przekształconych w wyniku działalności człowieka, a w szczególności powierzchnię ziemi, kopaliny, wody, powietrze, krajobraz, klimat oraz pozostałe elementy różnorodności biologicznej, a także wzajemne oddziaływania pomiędzy tymi elementami.

40 Filar ochronny jest to część obszaru górniczego, w której dla ochrony terenów, budowli i urządzeń naziemnych oraz podziemnych przed szkodami wskutek robót górniczych prowadzenie tych robót jest zastrzeżone i może być dozwolone w zakresie ustalonych kategorii ochrony, tj. w zależności od stopnia ważności i wrażliwości obiektów na odkształcenia; J. Olszewski, J. Osuchowski, i in., Leksykon górniczy, Katowice 1989, s. 71. 
czej i budowlanej, (b) koordynację robót górniczych i zapobiegawczo-naprawczych, (c) obserwacje obiektów budowlanych, (d) geodezyjne, geofizyczne i inne pomiary wskaźników deformacji oraz parametrów drgań gruntu powodowanych działalnością górniczą; (ppkt 3) zestawienie obiektów budowlanych oraz infrastruktury technicznej o kategorii odporności równej lub niższej od kategorii terenu górniczego w zasięgu wpływów projektowanej eksploatacji, z uwzględnieniem odporności dynamicznej na wstrząsy górnicze; (ppkt 4) prognozę wpływu działalności górniczej na środowisko, w szczególności w zakresie: (a) deformacji ciągłych, (b) deformacji nieciągłych, (c) drgań gruntu, (d) szkód w obiektach budowlanych oraz infrastrukturze technicznej, (e) zaburzeń warunków hydrologicznych przepływu wody w ciekach naturalnych i sztucznych oraz szkód w wodach powierzchniowych, (f) zmian stosunków wodnych, a zwłaszcza możliwości wystąpienia zalewisk terenowych i podtopień gruntu; (ppkt 5) zamierzenia w zakresie pomiarów deformacji terenu i obiektów budowlanych objętych wpływami projektowanej eksploatacji; (ppkt 6) ustalenia dotyczące sposobu przeciwdziałania i usuwania skutków projektowanej eksploatacji, ze szczególnym uwzględnieniem: (a) ochrony: powierzchni ziemi, sieci hydrograficznej, obiektów budowlanych oraz infrastruktury technicznej, (b) rekultywacji terenów niekorzystnie przekształconych w wyniku wydobywania kopalin.

W przekonaniu autora, dla sfery interesów prawnych właścicieli (użytkowników wieczystych) nieruchomości, położonych $\mathrm{w}$ granicach terenu górniczego, najbardziej doniosły wydaje się element planu ruchu podziemnego zakładu górniczego wymieniony w ppkt 6 pkt 24 załącznika nr 1 do cyt. rozporządzenia, w którym przedstawia się ustalenia dotyczące sposobu przeciwdziałania i usuwania skutków projektowanej eksploatacji.

W ocenie autora pomiędzy postanowieniami planu ruchu podziemnego zakładu górniczego przewidzianymi w pkt 23 i 24 załącznika nr 1 do rozporządzenia w sprawie planów ruchu a sferą interesów prawnych właścicieli (użytkowników wieczystych) nieruchomości, zlokalizowanych w granicach te- 
renu górniczego, istnieje związek. Nadto przywołane elementy planu ruchu mogą mieć znaczenie dla interesów prawnych innych jeszcze podmiotów. Przykładowo można tu wskazać na dzierżawców nieruchomości gruntowych oraz najemców lokali, położonych na terenach, które zgodnie z treścią zatwierdzanego planu ruchu podziemnego zakładu górniczego, miałyby zostać objęte wpływami eksploatacji górniczej. Zdaniem autora, powyższe korelacje nie uzasadniają jednak przyznania właścicielom (użytkownikom wieczystym) nieruchomości zlokalizowanych w granicach terenu górniczego, statusu stron postępowania w sprawie zatwierdzenia planu ruchu podziemnego zakładu górniczego. Podobnie, przewidywany wpływ ruchu podziemnego zakładu górniczego na sferę interesów prawnych pozostałych podmiotów zagrożonych tym ruchem, w tym dzierżawców gruntów i najemców lokali, nie pozwala na uznanie tych osób za strony postępowania administracyjnego dotyczącego zatwierdzenia planu ruchu podziemnego zakładu górniczego.

W powyższym kontekście warto zauważyć, że kolizję pomiędzy uprawnieniami przedsiębiorcy prowadzącego ruch zakładu górniczego a uprawnieniami właścicieli nieruchomości i innych podmiotów, których prawa majątkowe są zagrożone ruchem zakładu górniczego, ustawodawca w art. 144 ust. 1 p.g.g. ${ }^{41}$ generalnie rozstrzygnął na korzyść przedsiębiorcy ${ }^{42}$. Poza tym ochronę interesów prawnych właścicieli nieruchomości i innych podmiotów zagrożonych ruchem zakładu górniczego zapewniają regulacje działu VIII p.g.g., (zatytułowanego „Odpowiedzialność za szkody”). Ochrona praw wymienionych osób jest przy tym realizowana na drodze cywilnoprawnej, tzn. przed sądem powszechnym po uprzednim wyczerpaniu trybu postępowania ugodowego, określonego w art. 151 p.g.g. Należy

41 Zgodnie z art. 144 ust. 1 zd. 1 p.g.g., właściciel nie może sprzeciwić się zagrożeniom spowodowanym ruchem zakładu górniczego, który jest prowadzony zgodnie z ustawą. Stosownie do art. 144 ust. 2 ww. ustawy, przepis ust. 1 tego artykułu stosuje się odpowiednio do innych podmiotów, których prawa majątkowe są zagrożone ruchem zakładu górniczego.

42 Tak na tle art. 91 nieobowiązującej ustawy z dnia 4 lutego 1994 r. Prawo geologiczne i górnicze A. Lipiński i R. Mikosz, Ustawa ..., s. 441 i 442. 
również podkreślić, że odpowiedzialność przedsiębiorcy, który, prowadząc ruch zakładu górniczego, narusza sferę uprawnień właścicieli nieruchomości lub innych podmiotów, o których stanowi art. 144 ust. 2 p.g.g., ma charakter cywilnoprawny.

W przekonaniu autora, prawo własności lub prawo użytkowania wieczystego nieruchomości, położonej w granicach terenu górniczego, a w przypadku osoby, o której mowa w art. 144 ust. 2 p.g.g. - inne prawo majątkowe, nie stanowią praw refleksowych, z których mógłby wynikać interes prawny do bycia stroną postępowania administracyjnego $\mathrm{w}$ przedmiocie zatwierdzenia planu ruchu podziemnego zakładu górniczego. Właściciele (użytkownicy wieczyści) nieruchomości, zlokalizowanych w granicach terenu górniczego, oraz inne osoby, których prawa majątkowe mogą zostać zagrożone ruchem podziemnego zakładu górniczego zaprojektowanym w planie ruchu, który przedsiębiorca przedstawił do zatwierdzenia organowi nadzoru górniczego, mają natomiast interes faktyczny $\mathrm{w}$ postępowaniu dotyczącym zatwierdzenia tego dokumentu. Jednakże interes faktyczny nie wystarcza do przyznania określonemu podmiotowi przymiotu strony postępowania administracyjnego ${ }^{43}$.

\section{BIBLIOGRAFIA}

Jaśkowska M., Wróbel A., Kodeks postępowania administracyjnego. Komentarz, wyd. 3, Warszawa 2009.

Knysiak-Molczyk H., Glosa do wyroku NSA z dnia 6 czerwca 2006 r., sygn. akt II GSK 59/06, OSP 2007, nr 4, poz. 42.

Lipiński A., Mikosz R., Ustawa prawo geologiczne i górnicze. Komentarz, wyd. 2 zm., Warszawa 2003.

Łaszczyca G., Martysz C., Matan A., Kodeks postępowania administracyjnego. Komentarz do art. 1-103, tom I, wyd. 1, Kraków 2005.

43 Odnośnie rozróżnienia interesu prawnego od interesu faktycznego w postępowaniu administracyjnym por. wyroki WSA w Warszawie: z dnia 8 listopada 2011 r. (zob. przypis nr 30) i z dnia 22 listopada 2011 r. (zob. przypis nr 31). 
Mikosz R., Strona w postępowaniu dotyczacym koncesji na wydobywanie kopalin, [w:] Ratio est anima legis. Księga jubileuszowa ku czci Profesora Janusza Trzcińskiego, Warszawa 2007.

Olszewski J., Osuchowski J., i in., Leksykon górniczy, Katowice 1989. Poradnik górnika, tom 2, praca zbiorowa, wyd. 2 całkowicie zm. i uzup., Katowice 1975.

Kontakt e-mail:

lukaiwanski@gmail.com 